\title{
Borehole temperatures reveal details of 20th century warming at Bruce Plateau, Antarctic Peninsula
}

\author{
V. Zagorodnov ${ }^{1}$, O. Nagornov ${ }^{2}$, T. A. Scambos ${ }^{3}$, A. Muto $^{3, *}$, E. Mosley-Thompson ${ }^{1}$, E. C. Pettit ${ }^{4}$, and S. Tyuflin ${ }^{3}$ \\ ${ }^{1}$ Byrd Polar Research Center, The Ohio State University, Columbus, OH 43210, USA \\ ${ }^{2}$ Moscow Engineering Physics Institute, Kashirskoe Shosse 31, Moscow 115409, Russia \\ ${ }^{3}$ National Snow and Ice Data Center, CIRES, University of Colorado at Boulder, Boulder, CO 80309, USA \\ ${ }^{4}$ Department of Geology and Geophysics, University of Alaska Fairbanks, Fairbanks, AK 99775, USA \\ * now at: Dept. of Geosciences, Pennsylvania State University, State College, PA 16802, USA
}

Correspondence to: V. Zagorodnov (zagorodnov.1@osu.edu)

Received: 15 September 2011 - Published in The Cryosphere Discuss.: 2 November 2011

Revised: 20 April 2012 - Accepted: 10 May 2012 - Published: 15 June 2012

\begin{abstract}
Two ice core boreholes of $143.18 \mathrm{~m}$ and $447.73 \mathrm{~m}$ (bedrock) were drilled during the 2009-2010 austral summer on the Bruce Plateau at a location named LARISSA Site Beta $\left(66^{\circ} 02^{\prime} \mathrm{S}, 64^{\circ} 04^{\prime} \mathrm{W}, 1975.5 \mathrm{~m}\right.$ a.s.1.). Both boreholes were logged with thermistors shortly after drilling. The shallow borehole was instrumented for 4 months with a series of resistance thermometers with satellite uplink. Surface temperature proxy data derived from an inversion of the borehole temperature profiles are compared to available multi-decadal records from weather stations and ice cores located along a latitudinal transect of the Antarctic Peninsula to West Antarctica. The LARISSA Site Beta profiles show temperatures decreasing from the surface downward through the upper third of the ice, and warming thereafter to the bed. The average temperature for the most recent year is $-14.78^{\circ} \mathrm{C}$ (measured at $15 \mathrm{~m}$ depth, abbreviated $T_{15}$ ). A minimum temperature of $-15.8^{\circ} \mathrm{C}$ is measured at $173 \mathrm{~m}$ depth, and basal temperature is estimated to be $-10.2{ }^{\circ} \mathrm{C}$. Current mean annual temperature and the gradient in the lower part of the measured temperature profile have a best fit with an accumulation rate of $1.9 \times 10^{3} \mathrm{~kg} \mathrm{~m}^{-2} \mathrm{a}^{-1}$ and basal heat flux $(q)$ of $88 \mathrm{~mW} \mathrm{~m}^{-2}$, if steady-state conditions are assumed. However, the midlevel temperature variations show that recent temperature has varied significantly. Reconstructed surface temperatures $\left(T_{\mathrm{s}}=T_{15}\right)$ over the last $200 \mathrm{yr}$ are derived by an inversion technique (Tikhonov and Samarskii, 1990). From this, we find that cold temperatures (minimum $T_{\mathrm{s}}=-16.2^{\circ} \mathrm{C}$ ) prevailed from $\sim 1920$ to $\sim 1940$, followed by a gradual rise of temperature to $-14.2{ }^{\circ} \mathrm{C}$ around 1995 , then cooling over
\end{abstract}

the following decade and warming in the last few years. The coldest period was preceded by a relatively warm 19th century at $T_{15} \geq-15^{\circ} \mathrm{C}$. To facilitate regional comparisons of the surface temperature history, we use our $T_{15}$ data and nearby weather station records to refine estimates of lapse rates (altitudinal, adjusted for latitude: $\Gamma_{\mathrm{a}(1)}$ ). Good temporal and spatial consistency of $\Gamma_{\mathrm{a}(1)}$ over the last $35 \mathrm{yr}$ are observed, implying that the climate trends observed here are regional and consistent over a broad altitude range.

\section{Introduction}

Multiple studies from a variety of disciplines show that the Antarctic Peninsula (AP) is among the fastest-warming regions on the planet. Analyses of meteorological and glaciological data, satellite data and borehole observations display significant temporal and spatial climatic variability on the AP (Barrett et al., 2009; Lee et al., 2010; Monaghan et al., 2008; Nicholls and Paren, 1993; Rignot et al., 2004; Schneider and Steig, 2008; Turner et al., 2002; Vaughan et al., 2003). Climate warming in recent decades in the Bellingshausen Sea has been linked to the reduction of sea ice there (Jacobs and Comiso, 1997; Stammerjohn et al., 2008). Warming in the western AP is also associated with a large positive precipitation trend (Turner et al., 2005), possibly also linked to the loss of sea ice. Rapid disintegration of several ice shelves and retreat of tidewater glaciers in this region (Scambos et al., 2003; Cook et al., 2005) are also attributed to 
rising air temperatures (Doake and Vaughan, 1991; Vaughan and Doake, 1996; van den Broeke, 2005). In particular, the spectacular disintegration of the Larsen A and Larsen B ice shelves in 1995 and 2002, respectively, appears to have resulted from decades of warming in the region and an associated increase in surface melting (Vaughan and Doake, 1996; Scambos et al., 2003). A few ice core proxy records of temperature from the AP region, using several different means of inferring past temperature, document this rise of air temperature and accumulation rate during the last $100-150 \mathrm{yr}$ (Aristarain et al., 1990; Peel and Clausen, 1982; Peel et al., 1988; Thompson et al., 1994; Mosley-Thompson and Thompson, 2003; Schneider and Steig, 2008; Thomas et al., 2008, 2009).

To better understand the climatic changes of the central AP in the immediate vicinity of the Larsen B during the past few hundred years, two boreholes of $143.74 \mathrm{~m}$ and $447.65 \mathrm{~m}$ (latter one reached bedrock) were drilled during the austral summer of $2009-10$ on the Bruce Plateau at a site named LARISSA Site Beta (henceforth L-B) $\left(66^{\circ} 02^{\prime} \mathrm{S}\right.$, $64^{\circ} 04^{\prime} \mathrm{W}$; $1975.5 \mathrm{~m}$ a.s.1.). LARISSA (Larsen Ice Shelf System, Antarctica) is a multidisciplinary research project investigating the recent rapid environmental changes in the region. The ice cores will be evaluated for isotopic and other climate-related variations in a later study. For this work, multiple temperature profile measurements were made using a calibrated thermistor in two L-B Site boreholes. The site is in a key location, in close proximity to the remnant of the Larsen B (Scar Inlet Ice Shelf), active and recently retreated glaciers on the western AP, and the northernmost Larsen C. Both the shelf areas are thought to be vulnerable to retreat and break-up in the style of the 2002 Larsen B disintegration if the regional warming continues.

Borehole temperatures are a useful source of past climate information in areas of sparse long-term records and represent an independent and direct "memory" of the past surface temperatures. They allow reconstructions of past surface temperature based on inverse modeling, so long as key parameters (accumulation, densification of snow, ice thickness, geothermal heat flow, and physical properties of ice) can be adequately inferred from an understanding of glaciological and geological properties of the region (Harris and Chapman, 1997; Pollack and Huang, 2000; MacAyeal et al., 1991; Dahl-Jensen et al., 1998; van de Wal et al., 2002; Muto et al., 2011). This study attempts to determine the history of the surface mean annual temperature $\left(T_{\mathrm{S}}\right)$ as represented by the mean temperature at $15 \mathrm{~m}$ depth $\left(T_{15}\right)$ using an inversion technique (Nagornov et al., 2001) similar to the control method developed by MacAyeal et al. (1991). Considering that the detailed accumulation history of the site is as yet unknown and our assumptions that the basal heat flux is constant and heat generation from ice flow are negligible, we limited our $\mathrm{T}_{\mathrm{S}}$ reconstruction to the last $200 \mathrm{yr}$. Two other borehole temperature profiles in the AP region were measured earlier and $T_{\mathrm{S}}$ was reconstructed by inversion methods (Nicholls and Paren, 1993; Barrett et al., 2009). These ear- lier investigations on the AP produced results comparable to ours (presented below). However, neither our $T_{\mathrm{s}}$ reconstruction presented here nor any previous borehole thermal profile inversions have been directly validated by reconstructions based on stable isotope data. Forthcoming analyses of $\delta^{18} \mathrm{O}$ and $\delta \mathrm{D}$ in the L-B ice cores will provide a test of these results.

We also extract a preliminary value of the modern accumulation rate and basal heat flux for the site using a simple steady-state thermal model. Based on our measured $T_{15}$, reconstructed $T_{\mathrm{s}}$, and the measured temperatures from nearby AWS and conventional weather stations, we determine spatial and temporal lapse rates (change in temperature with latitude or with elevation, $\mathrm{d} T / \mathrm{d} x$ or $\mathrm{d} T / \mathrm{d} z$ : we refer to lapse rate here as as $\Gamma_{\mathrm{a}(1)}$, an altitudinal lapse rate corrected for latitude among various sites). A relatively constant lapse rate for the region gives us confidence that a single climate trend describes the pattern of temperature changes on the western side of AP for the past $\sim 50 \mathrm{yr}$.

In the following sections, we review the site characteristics of the Bruce Plateau summit and discuss the drilling and temperature measurements in detail. We then introduce the model and the initial steady-state approximation to set boundaries on accumulation and geothermal heat flux. We discuss the model result and compare it to other records (direct and proxy) of the climate history of the Antarctic Peninsula. We compare the implied lapse rate among some of the records to establish some confidence in using coastal and ridge crest records together, as they span some range of latitude. The data and comparisons support a strong regional pattern of early 1900s cooling and later rapid warming to the present; recent trends are mixed, but remain relatively warm.

\section{Site description}

The borehole site is at $66^{\circ} 02^{\prime} \mathrm{S}, 64^{\circ} 04^{\prime} \mathrm{W}$, approximately $2 \mathrm{~km}$ east of the present AP ice divide, and $1975.5 \mathrm{~m}$ above the EGM96 geoid. Thus, it lies between the catchments of the Larsen B Ice Shelf (Leppard Glacier, flowing to the northeast from the site) and the Larsen C Ice Shelf (Atlee Glacier to the southeast). To the west of the ridge crest, ice drains into Birely Glacier and Barilari Bay.

A geophysical site survey of surface topography, ice motion, ice thickness, and accumulation conducted in the month preceding the borehole drilling (December 2009; Pettit et al., 2011) revealed a significant accumulation gradient near the drill site, with much lower accumulation (60 to $80 \%$ of the near-summit rate) just $4 \mathrm{~km}$ to the east. Ice thickness varies greatly over the survey region, from a maximum of over $800 \mathrm{~m}$ to less than $400 \mathrm{~m}$ to the west. The site characteristics are shown in Table 1. Bedrock morphology appears to be a set of rolling hills, with distinct deeper troughs in the directions of the two glaciers fed by the summit catchment area. A weather station with a sonic accumulation sensor collected 
Table 1. LARISSA Site Beta, Bruce Plateau site characteristics.

\begin{tabular}{ll}
\hline Surface elevation & $\begin{array}{l}\text { divide: } 2012 \mathrm{~m} ; \\
\text { ice core site: } 1976 \mathrm{~m}\end{array}$ \\
\hline Thickness & $\begin{array}{l}\text { divide: } 460 \mathrm{~m} ; \\
\text { ice core site: } 447 \mathrm{~m}\end{array}$ \\
Distance east of the divide & $\sim 2 \mathrm{~km}$ \\
Surface slope & $\sim 0.025$ at the core site \\
Surface velocity & $10(+/-4) \mathrm{m} \mathrm{yr}^{-1}$ \\
15 m temperature (average annual) & $-14.8^{\circ} \mathrm{C}$ \\
Accumulation rate $(1963-2010):$ & $\sim 2 \mathrm{~m} \mathrm{yr}^{-1}$ \\
Pore close-off depth & $80 \mathrm{~m}$ \\
Bed temperature & $-10.2^{\circ} \mathrm{C}$ \\
Geothermal flux & $88 \mathrm{~mW} \mathrm{~m}^{-2}$ \\
\hline
\end{tabular}

data for 5 months before being buried. It revealed an accumulation rate in excess of $3 \mathrm{~m}$ per year water equivalent. However, the 2010 season may have been anomalous due to an intense pattern of westerly winds and high southern annular mode (SAM) index during the 2010 austral winter (see e.g. http://www.antarctica.ac.uk/met/gjma/sam.html).

\section{Drilling}

Ice coring was carried out with a dry hole electromechanical drill (EMD) and an ethanol thermal-electric drill (ETED; Zagorodnov et al., 1998). The drilling program at the LB site spanned 42 days in December-February 2009-2010. The first borehole (L-Ba) was drilled to $143.74 \mathrm{~m}$ depth on 3 January 2010 with the EMD; the second (L-Bb) was drilled $1.2 \mathrm{~m}$ from L-Ba down to $178.5 \mathrm{~m}$ with the EMD, and then to the bedrock at $447.65 \mathrm{~m}$ with the ETED (Zagorodnov et al., 1998, 2005). During the operation, the borehole fluid (ethanol-water solution) used with the ETED was lowered (by bailing) to a depth of $244 \mathrm{~m}$. Many aspects of the drilling at the L-B site, including the sticking and subsequent extraction of the drill, are similar to those experienced during the Bona-Churchill ice coring project in 2003 (Zagorodnov et al., 2005).

\section{Temperature measurements}

Two temperature measurement systems were used: (1) a calibrated profiling thermistor on the drilling cable and (2) a string of 17 calibrated platinum resistance thermometers (PRT) installed in L-Ba and equipped with a recording and telemetry system. The downhole temperature profiling probe consisted of a hermetically sealed glass encapsulated thermistor $\left(100 \mathrm{kOhm}\right.$ at $\left.-20^{\circ} \mathrm{C}\right)$. It was calibrated with the reference thermometer to a precision of $0.1^{\circ} \mathrm{C}$. The time constant of the probe is $10 \mathrm{~min}$ in air and $1 \mathrm{~min}$ in fluid. The probe was lowered into the borehole on a two-conductor electromechanical drilling cable with a loop resistance of
5 Ohms. Variations of the loop resistance with temperature are two orders of magnitude less than those in the thermistor and are neglected. The drilling setup depth readout has $1 \mathrm{~mm}$ resolution. According to the cable specifications, the maximum cable elongation during the temperature measurements is $\sim 0.3 \mathrm{~m}$ or $0.14 \%$ of maximum borehole depth. Thus, the precision of the probe positioning in the borehole is conservatively assumed to be $\sim 0.05 \mathrm{~m}$. During measurements the probe was held at the specified depth for 20-30 $\mathrm{min}$ in the dry section of the borehole and for 3-5 min in the fluid-filled part of the borehole.

The first temperature measurements in L-Ba were conducted five days after completion of the borehole drilling on 8 January 2010 , or nine days after drilling at $15 \mathrm{~m}$ depth. The first temperature measurements in $\mathrm{L}-\mathrm{Bb}$ were performed on 17 January (borehole depth $305 \mathrm{~m}$ ), or eight days after drilling at $15 \mathrm{~m}$ depth. Temperature discrepancies between the borehole thermistor logs did not exceed $0.1^{\circ} \mathrm{C}$ at any depth (Table 2). Similar or smaller temperature discrepancies were found during the last temperature measurements on 1 February 2010, two days after L-Bb reached the bedrock and five days after drilling to $430.9 \mathrm{~m}$ depth. Data below $430.9 \mathrm{~m}$ depth were excluded from the analyses. We used the 1 February record for the inversion analysis (Table 2). According to our experimental data obtained in fluid-filled boreholes (Zagorodnov et al., 1994), temperature disturbance caused by drilling dissipates to the level of precision of our measurements within five days.

The PRT string was left in the open hole, but this was quickly covered and partially filled by wind prior to 1 March 2010, the start of the temperature record we present (Table 2). Temperatures were recorded hourly and compiled into monthly means. Estimated error of mean value for open-hole measurements is $0.05^{\circ} \mathrm{C}$. Temperatures between the two systems from similar depths below $15 \mathrm{~m}$ agree to within $0.1^{\circ} \mathrm{C}$ (e.g. at $\sim 16, \sim 40$, and $\sim 120 \mathrm{~m}$; see Table 2 ).

It was found that the temperature at $15 \mathrm{~m}$ depth $\left(T_{15}\right)$ is $-14.78^{\circ} \mathrm{C}$, which is inferred to be close to the mean annual temperature for the preceding year. A minimum temperature of $-15.8^{\circ} \mathrm{C}$ was measured at $173 \mathrm{~m}$ depth, and the bottom temperature was estimated to be $-10.2{ }^{\circ} \mathrm{C}$.

A previous study in Greenland of a dry borehole equilibration disturbed by drilling showed that the temperature measured at the borehole bottom soon after dry hole electromechanical drilling is about $1{ }^{\circ} \mathrm{C}$ higher than after equilibrium is attained. There are a few processes that disturb borehole temperature: (1) the major heat source is cutting of snowice-firn with the drill; (2) depending on air temperature, surface solar radiation, borehole depth, and the drill can be a source or sink of heat; (3) air motion induced by drill lowering and raising could introduce or remove heat from the borehole; and (4) natural air circulation in the snow-firn and borehole could cause short-term temperature fluctuations at any depth in the borehole. Our observations show that most of the heat introduced to the borehole by drilling operations 


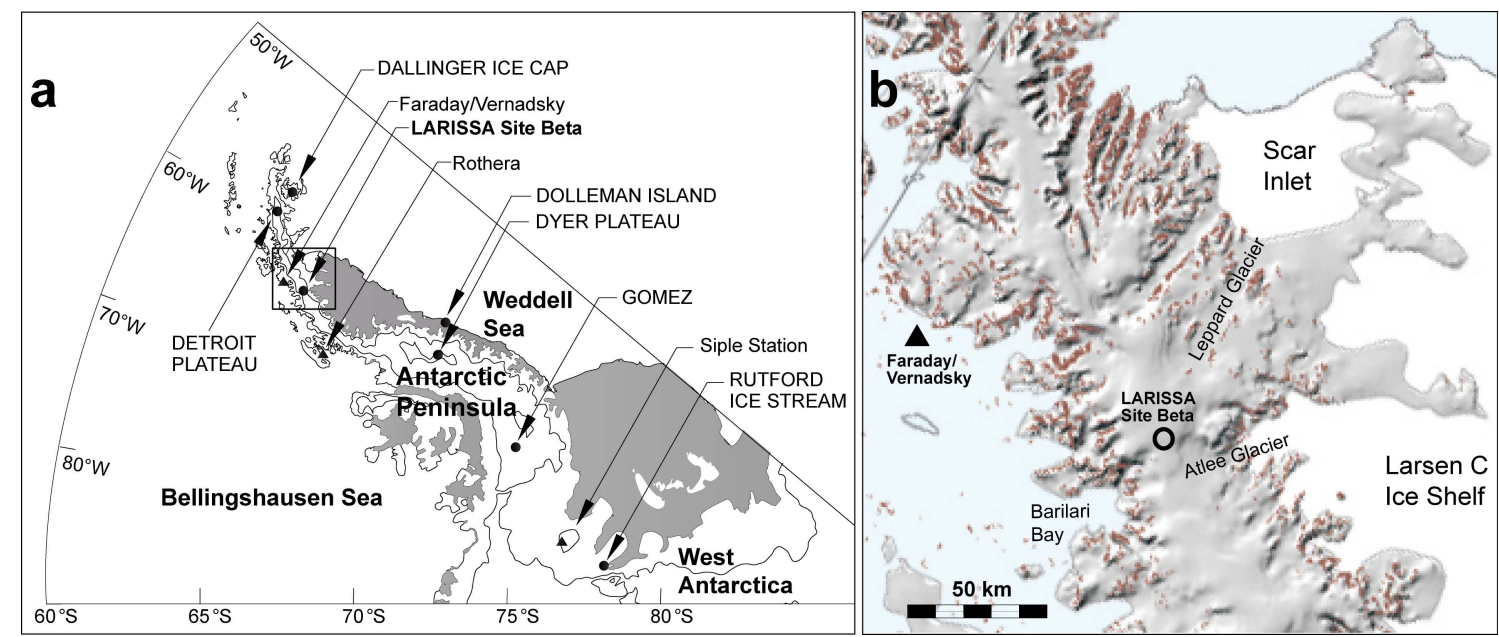

Fig. 1. Maps of the study area. (a) Overview of sites used for latitudinal assessment of climate trends; inset box is area of (b). Panel (b) shaded relief map of the LARISSA Site Beta area (modified from a British Antarctic Survey base map for the region). Triangles are weather station locations; circles are ice core sites.

is dissipated within $24 \mathrm{~h}$. Morris and Vaughan (1994, 2003) pointed out that in boreholes of $10 \mathrm{~m}$ depth or less, measured temperatures depend on the calendar date of measurements and may differ from the equilibrated temperatures by $\pm 0.1^{\circ} \mathrm{C}$. Paterson (1994) provides an example of observed annual temperature waves of $0.85^{\circ} \mathrm{C}$ and $0.2^{\circ} \mathrm{C}$, respectively at $10 \mathrm{~m}$ and $16 \mathrm{~m}$ depth but also notes other observations with no annual temperature variations (within $\pm 0.1{ }^{\circ} \mathrm{C}$ ) at $11 \mathrm{~m}$ depth. Thus, it is reasonable to conclude that the depth of the mean annual temperature for a given site depends on the local snow-firn-ice properties, accumulation rate and possibly wind conditions. Four months of temperature monitoring (March through July of 2010) with the PRT string installed in L-Ba revealed little change from the temperature values measured nine days after drilling for depths greater than $15 \mathrm{~m}$ (Table 2).

Most of the borehole temperature data on the Antarctic Peninsula, including that from the Detroit Plateau site discussed below, were obtained from $10 \mathrm{~m}$ depth boreholes drilled with a hand auger and measured within hours of the completion of drilling. Drilling with a hand auger in snow and firn could be considered as less thermodynamically intrusive than EM drilling (i.e. less disturbance of firn temperatures). However, estimates of the power exerted during hand augering are 300-400 W. Hand augering rates (below the top few meters) are at best $2-3 \mathrm{~m} \mathrm{~h}^{-1}$. The same parameters for EM drilling are $100 \mathrm{~W}$ and $10-15 \mathrm{~m} \mathrm{~h}^{-1}$ at $10 \mathrm{~m}$ depth. Hence, energy dissipation with hand augering is likely higher than EM drilling. Therefore, borehole temperatures from $10 \mathrm{~m}$ boreholes measured within $10-12 \mathrm{~h}$ of drilling are likely to be a fraction of a ${ }^{\circ} \mathrm{C}$ higher than the equilibrated borehole temperature and could be affected by seasonal temperature variations.
The four-month temperature series in L-Ba of 12 PRT shows seasonal temperature variations of $0.1^{\circ} \mathrm{C}$ at $10 \mathrm{~m}$, but near-uniform temperatures at $15 \mathrm{~m}$ and below $\left(< \pm 0.05^{\circ} \mathrm{C}\right.$, Table 2). Therefore, at the L-B site $T_{15}$ was assumed to equal the mean annual air temperature and the following $T_{\mathrm{s}}$ reconstructions and lapse rate estimates are made for $15 \mathrm{~m}$ depth. These observations validate that high vertical advection (modeled at $1.9 \times 10^{3} \mathrm{~kg} \mathrm{~m}^{-2} \mathrm{a}^{-1}$, see below) significantly increases the depth of the annual temperature wave attenuation.

Results of temperature measurements in L-Ba and L-Bb are shown in Fig. 2. Continuous temperature monitoring over several days for $\mathrm{L}-\mathrm{Bb}$ and over four months for L-Ba greatly reduced the uncertainty of the final temperature profile used for modeling. The data presented here (Fig. 2, Table 2) have errors of approximately $\pm 0.1^{\circ} \mathrm{C}$ or less. The measurements in the adjacent boreholes agree to within $\pm 0.1{ }^{\circ} \mathrm{C}$.

\section{Model}

Temperature distribution in an ice sheet over a period of time $\left[0, t_{\mathrm{f}}\right]$ is represented by the solution of the following equation relating the time change in temperature to the diffusion, advection, and viscous heating within the ice:

$\rho C \frac{\partial T}{\partial t}=\nabla \cdot k \nabla T+\rho C \boldsymbol{u} \cdot \nabla T+\dot{\varepsilon} \sigma$

where $T$ is the temperature, $\rho$ is the ice density, $C$ is the specific heat capacity, $k$ is the thermal conductivity, $\boldsymbol{u}$ is the ice velocity, and $\dot{\varepsilon} \sigma$ is a term representing the viscous heating term ( $\dot{\varepsilon}$ is the strain rate tensor and $\sigma$ is the stress tensor). In our forward model we make three assumptions. First, we assume that the viscous heating term is negligible relative to 
Table 2. Borehole Temperature measurements at LARISSA Site Beta, Bruce Plateau.

\begin{tabular}{|c|c|c|c|c|c|c|c|c|c|}
\hline \multicolumn{4}{|c|}{ Thermistor Logging 1} & \multirow{2}{*}{\multicolumn{6}{|c|}{$\frac{\text { PRT Temperature Monitoring }^{2}}{\text { Borehole L-Ba }}$}} \\
\hline \multicolumn{2}{|c|}{ Borehole L-Ba } & \multicolumn{2}{|c|}{ Borehole L-Bb } & & & & & & \\
\hline Depth, m & $T_{\operatorname{Jan} 08},{ }^{\circ} \mathrm{C}$ & Depth, m & $T_{F e b 01},{ }^{\circ} \mathrm{C}$ & $\mathrm{Depth}^{3}, \mathrm{~m}$ & $T_{\text {March }},{ }^{\circ} \mathrm{C}$ & $T_{\text {April }},{ }^{\circ} \mathrm{C}$ & $T_{\text {May }},{ }^{\circ} \mathrm{C}$ & $T_{\text {June }},{ }^{\circ} \mathrm{C}$ & $T_{a v g},{ }^{\circ} \mathrm{C}$ \\
\hline $\begin{array}{l}16.82 \\
21.02\end{array}$ & $\begin{array}{l}-14.68 \\
-14.75\end{array}$ & $\begin{array}{r}8.41 \\
10.51 \\
\\
21.02 \\
42.04 \\
\\
63.06 \\
84.09 \\
105.11 \\
126.13 \\
147.15 \\
168.17 \\
189.19 \\
210.21 \\
231.24 \\
252.26 \\
273.28 \\
294.30 \\
315.32 \\
336.34 \\
357.36 \\
378.86 \\
400.77 \\
409.92 \\
420.43 \\
430.94\end{array}$ & $\begin{array}{l}-15.35 \\
-15.30 \\
-14.75 \\
-14.70 \\
-14.78 \\
-15.07 \\
-15.40 \\
-15.61 \\
-15.70 \\
-15.77 \\
-15.77 \\
-15.84 \\
-15.68 \\
-15.21 \\
-15.16 \\
-14.90 \\
-14.53 \\
-13.98 \\
-13.39 \\
-12.70 \\
-11.93 \\
-11.61 \\
-11.29 \\
-10.82\end{array}$ & $\begin{array}{r}2.5 \\
3.0 \\
5.0 \\
10.0 \\
16.0 \\
24.0 \\
32.0 \\
40.0 \\
55.0 \\
70.0 \\
90.0 \\
\\
120.0\end{array}$ & $\begin{array}{l}-13.86 \\
-14.26 \\
-15.20 \\
-15.12 \\
-14.72 \\
-14.71 \\
-14.69 \\
-14.70 \\
-14.76 \\
-14.93 \\
-15.22 \\
-15.57\end{array}$ & $\begin{array}{l}-13.90 \\
-14.19 \\
-14.98 \\
-15.10 \\
-14.74 \\
-14.71 \\
-14.70 \\
-14.70 \\
-14.77 \\
-14.95 \\
-15.23 \\
-15.56\end{array}$ & $\begin{array}{l}-14.07 \\
-14.23 \\
-14.84 \\
-15.07 \\
-14.76 \\
-14.71 \\
-14.71 \\
-14.72 \\
-14.80 \\
-14.93 \\
-15.22 \\
-15.57\end{array}$ & $\begin{array}{l}-14.44 \\
-14.48 \\
-14.77 \\
-15.03 \\
-14.78 \\
-14.72 \\
-14.68 \\
-14.71 \\
-14.81 \\
-14.94 \\
-15.23 \\
-15.57\end{array}$ & $\begin{array}{l}-14.07 \\
-14.29 \\
-14.95 \\
-15.08 \\
-14.75 \\
-14.71 \\
-14.69 \\
-14.71 \\
-14.78 \\
-14.94 \\
-15.23 \\
-15.57\end{array}$ \\
\hline
\end{tabular}

\footnotetext{
${ }^{1}$ Temperature precision for all thermistor measurements is $\pm 0.05^{\circ} \mathrm{C}$. See text for averaging times.

2 Temperature precision for all monthly-averaged PRT measurements is $\pm 0.05^{\circ} \mathrm{C}$.

${ }^{3}$ Nominal depths at the time of installation in early February. Rapid accumulation changed the depths during the period of monitoring: March, add $0.7 \mathrm{~m}$; April, add $1.3 \mathrm{~m}$; May, add $2.0 \mathrm{~m}$; June, add $3.8 \mathrm{~m}$; Average (shown in Fig. 2)triangles, add $2.0 \mathrm{~m}$.
}

the other terms (heating of the deforming layer becomes substantial at $>800 \mathrm{~m}$ depth; e.g. Radok et al., 1970). The magnitude of the viscous heating term can be characterized by estimating a characteristic strain rate $\left(\dot{\varepsilon}_{\text {char }}=\dot{b} / H\right)$ and stress $\left(\tau_{\text {char }}=\left(\dot{\varepsilon}_{\text {char }} /_{A}\right)^{1 / 3}\right.$ ) for the divide (Pettit and Waddington, 2003). For the Bruce Plateau, this characteristic strain heating is of the order $9 \times 10^{-6} \mathrm{~W} \mathrm{~m}^{-3}$, which is small relative to the other terms. Similar calculations justifying elimination of internal heating terms are presented in Nagornov et al. (2006) and Price et al. (2002).

Second, we assume that although the horizontal and vertical velocities are of comparable magnitude, the temperature gradient in the horizontal dimension is negligible relative to the vertical gradient. We, therefore, assume that we can use a one dimensional model in the vertical direction.
In making this assumption, we estimate the heat produced due to vertical advection in the snow near the surface as $\sim 10^{-3} \mathrm{~W} \mathrm{~m}^{-3}$. In order for horizontal advection to be neglected (be at least an order of magnitude smaller than vertical advection), our horizontal temperature gradient must be smaller than $0.002{ }^{\circ} \mathrm{C} \mathrm{m}^{-1}$ (or $2{ }^{\circ} \mathrm{C} \mathrm{km}^{-1}$ ). This is much larger than the horizontal temperature gradients present at the Bruce Plateau surface.

Finally, we assume that past variations in the flow field, $\boldsymbol{u}$, due to migration and thickening or thinning of the ice divide in the past $200 \mathrm{yr}$, have had a negligible effect on the temperature field compared to past variations in the surface temperature and accumulation rate. Models of changes in the flow field suggest that the ice core site has likely been 1 to $2 \mathrm{~km}$ to the east of the divide for the past century and probably longer (Pettit et al., 2011). 

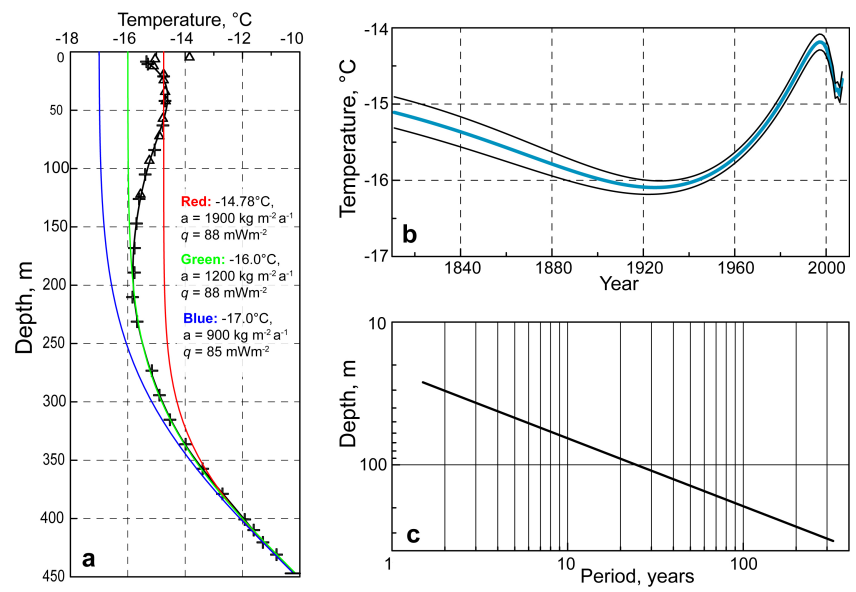

Fig. 2. (a) Borehole temperatures measured at LARISSA Site Beta and steady state model results used for estimating the range of geothermal heat flux and mean accumulation. Crosses are the thermistor-measured values for L-Bb; triangles are PRT-measured mean temperatures in L-Ba spanning five months; the colored lines are steady state model results that bound the likely range of conditions for the profile (see the text for the parameters). Panel (b) is the inverted $T$ s temperature history (blue) and possible error (black) proportional to instrumental inaccuracy of $0.1^{\circ} \mathrm{C}$; panel (c) is attenuation depth of surface temperature oscillations in the glacier.

Considering these assumptions, we can refine the model describing temperature history at the L-B ice core site (Nagornov et al., 2006):

$$
\begin{aligned}
& \rho(z) C(z) \frac{\partial T(z, t)}{\partial t}=\frac{\partial}{\partial z}\left[k(z) \frac{\partial T(z, t)}{\partial z}\right] \\
& \quad-\rho(z) C(z) w(z) \frac{\partial T(z, t)}{\partial z}, \\
& 0<z<H, \\
& 0<t<t_{\mathrm{f}}, \\
& \frac{\partial T}{\partial z}(H, t)=-\frac{q}{k(H)}, \\
& T(0, t)=U_{0}+\mu(t), \\
& T(z, 0)=U(z),
\end{aligned}
$$

where time $t_{\mathrm{f}}$ corresponds to the end of the period; time 0 corresponds to the initial time; $H$ is the thickness of the ice; $\rho(z)$ is the ice density as a function of depth $z ; C(z)$ is the specific heat capacity; $k(z)$ is the thermal conductivity; $q$ is the basal heat flux; $U_{0}$ is the surface temperature; $\mu(t)$ is the deviation of surface temperature from the initial value $(\mu(0)=0) ; w(z)$ is the advection or vertical velocity; and $U(z)$ is the initial temperature distribution.
An initial temperature profile $U(z)$ in the ice sheet may be represented by the solution of the following equation:

$$
\begin{aligned}
& \frac{\mathrm{d}}{\mathrm{d} z}\left[k(z) \frac{\mathrm{d} U(z)}{d z}\right]-\rho(z) C(z) w(z) \frac{\mathrm{d} U(z)}{\mathrm{d} z}=0, \\
& 0<z<H, \\
& \frac{\mathrm{d} U}{\mathrm{~d} z}(H)=-\frac{q}{k(H)} \\
& U(0)=U_{0}
\end{aligned}
$$

The specific heat capacity and thermal conductivity are approximated by the empirical formulae presented in Paterson (1994):

$C=(2098+7.122 T), \mathrm{Jkg}^{-1} \mathrm{~K}^{-1}$

$\mathrm{k}=9.828 \mathrm{e}^{-0.0057(273.15+T)}, \mathrm{W} \mathrm{m}^{-1} \mathrm{~K}^{-1}$

The density profile was approximated by Salamatin (2000) as

$$
\rho=\rho_{\text {ice }}\left(1-c_{0} e^{-\gamma z}\right) \text {, }
$$

where ice density $\rho_{\text {ice }}=(916.8-0.14027 T), \mathrm{kg} \mathrm{m}^{-3}, c_{0} \approx$ 0.58 , and $\gamma \approx 0.021, m^{-1}$.

Vertical velocity at the surface is assumed to balance the mean accumulation rate (i.e. no surface elevation change) and to decline linearly with depth to zero at the base of the ice sheet.

Assuming a steady state ice sheet (i.e. constant thickness and no basal melting), our measured borehole temperature profiles provide a target for model determinations of the terrestrial heat flow $q$ (assumed constant) and temporal variations in $T_{\mathrm{s}}$ and accumulation. Assuming a steady-state temperature gradient in the lower section of the borehole allows us to extrapolate below $430.9 \mathrm{~m}$ to the bed and refine our estimate of $q$. The three steady state profiles shown in Fig. 2 represent the reasonable range of centennial boundary conditions. The red line represents constant $T_{\mathrm{s}}=-14.78^{\circ} \mathrm{C}$, accumulation $\stackrel{\circ}{a}=1.9 \times$ $10^{3} \mathrm{~kg} \mathrm{~m}^{-2} \mathrm{y}^{-1}$ and $q=88 \mathrm{~mW} \mathrm{~m}^{-2}$; the green line is the result for $T_{s}=-16.0^{\circ} \mathrm{C}, \stackrel{a}{a}=1.2 \times 10^{3} \mathrm{~kg} \mathrm{~m}^{-2} \mathrm{y}^{-1}$ and $q=$ $88 \mathrm{~mW} \mathrm{~m}^{-2}$; and the blue line shows the result for $T_{S}=$ $-17.0^{\circ} \mathrm{C}, \stackrel{\leftrightarrow}{a}=0.9 \times 10^{3} \mathrm{~kg} \mathrm{~m}^{-2} \mathrm{y}^{-1}$ and $q=85 \mathrm{~mW} \mathrm{~m}^{-2}$.

The above boundary conditions were used to reconstruct $T_{\mathrm{S}}$ over the $200 \mathrm{yr}$ preceding 2010 . The Tikhonov regularization method (Nagornov et al., 2001, 2006; Tikhonov and Samarskii, 1990) was used for the reconstruction of $T_{\mathrm{s}}$. The inverted $T_{\mathrm{S}}$ is shown in Fig. 2.

\section{Discussion}

\subsection{Basal temperature and heat flux}

Extrapolated and modeled bottom temperature at the L-B site is $T_{\mathrm{b}}=-10.17 \pm 0.2^{\circ} \mathrm{C}$. The steady state model reveals 
a relatively high basal heat flux, $q=85-88 \mathrm{~mW} \mathrm{~m}^{-2}$, compared to the average continental geothermal heat flux $Q=$ $65 \mathrm{~mW} \mathrm{~m}^{-2}$ (Pollack et al., 1993). $Q$ refers to the geothermal heat flux not subjected to past climate changes, and $q$ represents the heat flux at the base of glaciers that are subject to past climate changes or/and glacier dynamical changes. The estimated mean $Q$ over most of Antarctica varies between 37 and $64 \mathrm{~mW} \mathrm{~m}^{-2}$ (Siegert and Dowdeswell, 1996). About $70 \%$ of the known subglacial lakes in Antarctica are found where the one-dimensional heat transfer model (similar to our model) predicts bottom melting. These regions have a mean $Q$ value of $54 \mathrm{~mW} \mathrm{~m}^{-2}$.

In the AP region there are few borehole temperature data and models that provide $q$ and $Q$ values for comparison with our results. Two geophysical models (Pollack et al., 1993; Shapiro and Ritzwoller, 2004) yield an average $Q$ of 90-100 $\mathrm{mW} \mathrm{m}^{-2}$ for the AP. Using a magnetic field model, Maule et al. (2005) estimated a mean $Q$ of $50-60 \mathrm{~mW} \mathrm{~m}^{-2}$. Glacier thermodynamic models, similar to that in our study, also suggest an above-average $q$ of $90-100 \mathrm{~mW} \mathrm{~m}^{-2}$ at the Dolleman Island site (Nicholls and Paren, 1993). A steady state model with relatively stable measured boundary conditions ( $T_{\mathrm{S}}$ calibrated from isotopes and measured accumulation) over the last $400 \mathrm{yr}$ at Dyer Plateau (Thompson et al., 1994) provides an estimate of $q=42 \mathrm{~mW} \mathrm{~m}^{-2}$ there. More distant from the AP region, above average values of $q$ (75.1 and $69 \mathrm{~mW} \mathrm{~m}^{-2}$ ) were reported at Law Dome (Dahl-Jensen et al., 1999) and Siple Dome (Engelhardt, 2004), respectively. Thus, our results for $q$ are at the high end but within the range of those measured elsewhere in the AP and comparable to some values measured elsewhere in Antarctica.

According to Waddington (1987) both above and below average $q$ values in ice sheet areas of shallow and intermediate thickness can be considered as a slowly varying parameter that is dependent not only on current boundary conditions but also on the previous climatic and dynamic history of the specific area on the glacier. At the L-B site, the ice dynamics has a large vertical component and therefore bottom conditions depend on the $T_{\mathrm{S}}$ history. Waddington (1987) and Ritz (1987) show that basal conditions $\left(T_{\mathrm{b}}\right.$ and $\left.q\right)$ are subject to climate perturbations. For a model to attain accurate results for a $3-\mathrm{km}$ thick ice sheet, another $2-4 \mathrm{~km}$ rock layer below the ice has to be assumed. In thinner glaciers the bottom conditions are more sensitive to changes on the surface. However, for the short-term (200 yr) surface condition reconstructions considered here, the bottom boundary conditions can be set as constant, although they may not represent the longer-term (multi-millennia) mean.

Firn and ice diffuse the high frequencies in the climate temperature signal that propagates from the surface downward. In the case of an ice sheet, the temperature oscillations propagate due to the combined effect of heat conduction and the vertical advection rate. Near the surface the main mechanism of heat propagation is vertical advection. At some depth, conduction becomes the primary mechanism.
Figure $2 \mathrm{c}$ shows how the periodic climatic signal from the surface attenuates with depth. The bottom axis of the graph indicates the approximate temporal filtering scale of surface temperature oscillations; the left axis of the graph shows the depth of penetration of these periodicities.

One implication of the relatively high $q$ we derive for the L-B site is that the critical ice thickness, at which bottom melting occurs, will be thinner than for many other Antarctic regions ("critical thickness" is a term suggested by Zotikov, 1986). Using a steady state model, we derive a critical thickness of $\sim 650 \mathrm{~m}$, even when surface conditions vary over a large range ( $\stackrel{a}{a}=0.9$ to $1.9 \times 10^{3} \mathrm{~kg} \mathrm{~m}^{-2} \mathrm{a}^{-1}$ and $T_{\mathrm{s}}=-17.0$ to $-14.8^{\circ} \mathrm{C}$ ). Radio-echo sounding profiles for the region (Pettit et al., 2011) demonstrate significant ice thickness variations. Areas of thicknesses exceeding of $650 \mathrm{~m}$ are present a few $\mathrm{km}$ to the northeast and southeast at the uppermost reaches of the Leppard and Atlee glacier catchments. Therefore, bottom melting probably occurs relatively high up in these glacier systems and subglacial lakes similar to those detected under the West and East Antarctic Ice Sheet are possible. Moreover, there is evidence for active subglacial lakes in the area (Zotikov, 1963; Duxbury et al., 2001; Fricker et al., 2007; Scambos et al., 2011). Internal deformation and basal sliding of the glacier could provide additional heat, and thus bottom melting could occur at ice thicknesses less than $650 \mathrm{~m}$.

\subsection{Accumulation rate}

Analyses of geographical and historical instrumental data (Turner et al., 2002) demonstrate significant temporal and spatial variations of accumulation in the AP region due to the specifics of topography, snow surface erosion and snow re-deposition. A large west-to-east gradient in accumulation exists due to orographic effects and the westerly mean wind pattern. The recent mean annual accumulation in the Bruce Plateau region was found to be about $2 \times 10^{3} \mathrm{~kg} \mathrm{~m}^{-2} \mathrm{a}^{-1}$ (Turner et al., 2002). This regional value is supported by the results from a high-spatial-resolution regional atmospheric model (van Lipzig et al., 2004) that also gives an estimated average value for the entire AP region of $1.2 \times 10^{3} \mathrm{~kg} \mathrm{~m}^{-2} \mathrm{a}^{-1}$. Shallow ice cores taken in the general region of the L-B site in $1975\left(64^{\circ} 05^{\prime} \mathrm{S}, 59^{\circ} 35^{\prime} \mathrm{W}\right.$ and $66^{\circ} 25^{\prime} \mathrm{S} ; 64^{\circ} 57^{\prime} \mathrm{W}$, Peel and Clausen, 1982) indicate mean accumulation rates of $2.7 \times 10^{3} \mathrm{~kg} \mathrm{~m}^{-2} \mathrm{a}^{-1}$ and $0.661 \times$ $10^{3} \mathrm{~kg} \mathrm{~m}^{-2} \mathrm{a}^{-1}$, respectively. Mean precipitations at the two weather stations closest to the L-B site, Faraday/Vernadsky and Palmer, are $1.045 \times 10^{3}$ and $0.77 \times 10^{3} \mathrm{~kg} \mathrm{~m}^{-2} \mathrm{a}^{-1}$, respectively (Turner et al., 2002). From 1956 to 1993 the frequency of precipitation events increased by about $40 \%$ at the Faraday/Vernadsky Station (Turner et al., 1997, 2005). Ice core data from the Dyer Plateau, Siple Station, and most recently from the Gomez ice core reveal a considerable increase in accumulation during the past $150 \mathrm{yr}$ up to $100 \%$ (Thomas et al., 2008; Thompson et al., 1994; 
Mosley-Thompson et al., 1991). The most recent comprehensive climate model (RACMO-2, as shown in van den Broeke, 2005) yields an accumulation rate of $\stackrel{\circ}{a}=2.5 \times$ $10^{3} \mathrm{~kg} \mathrm{~m}^{-2} \mathrm{a}^{-1}$ for the Bruce Plateau region. In general, both model results and ours are in agreement for the region. Other instrumental results at lower elevations or at different latitudes along the Antarctic Peninsula show substantial differences, but these likely reflect the strong temperature and precipitation gradients.

\subsection{Surface temperatures and regional lapse rates}

We examine the relationship among local temperature records on the western side of the AP and along its crest in the vicinity of the L-B site using borehole temperatures and weather station data. Two weather stations are used in this study, Faraday/Vernadsky (FV) and Rothera (RO), as they have the longest and least interrupted records compared to other stations in the region. Moreover, these stations are often used to represent the region in climate reconstructions. The temperature records from the stations exhibit large interannual variability but show a significant rise in mean annual temperature over the last 40 to $55 \mathrm{yr}$.

Temperatures reconstructed by inverse methods for the L$B$ site are subject to the attenuation of high frequency temperature variations with depth (i.e. further back in time). Thus, to facilitate a comparison with instrumental data, the station temperature records should be averaged as well. We applied an 11-yr unweighted running mean to the annual temperature records for the two stations to facilitate their comparison with the reconstructed borehole temperature record (Figs. 2 and 4).

Using the approach introduced by Morris and Vaughan (1994, 2004), we limited our study to a comparison of the reconstructed temperatures with the two closest weather stations: Faraday/Vernadsky and Rothera. The intent of the analysis is an examination of the consistency of temperature trends in the records, when adjusted for altitude and latitude. We extract a latitude-adjusted lapse rate from the Ts temperature history at LARISSA Site Beta (L-B) relative to the two weather stations by the following equation:

$$
\begin{aligned}
& T_{\mathrm{L}-\mathrm{B}}=T_{\mathrm{WS}}+S+\Gamma_{\mathrm{a}(1)} \Delta E \text { or } \\
& \Gamma_{\mathrm{a}(1)}=\frac{T_{\mathrm{L}-\mathrm{B}}-\left(T_{\mathrm{WS}}+S\right)}{\Delta E},{ }^{\circ} \mathrm{C} / 100 \mathrm{~m},
\end{aligned}
$$

where $T_{\mathrm{L}-\mathrm{B}}$ and $T_{\mathrm{WS}}$ are the mean annual temperature $\left({ }^{\circ} \mathrm{C}\right)$; $S=\left(L_{\mathrm{L}-\mathrm{B}}-L_{\mathrm{WS}}\right) \frac{T_{\mathrm{RO}}-T_{\mathrm{FV}}}{L_{\mathrm{RO}}-L_{\mathrm{FV}}}$ is a latitudinal correction coefficient (in ${ }^{\circ} \mathrm{C}$ ); $\Gamma_{\mathrm{a}(1)}$ is the altitudinal temperature lapse rate adjusted to a latitude (in ${ }^{\circ} \mathrm{C}$ ); $\Delta E=h_{\mathrm{L}-\mathrm{B}}-h_{\mathrm{WS}}$ is elevation difference between sites $(m) ; h$ is the site elevation (m a.s.l.); $L$ is the latitude of the site (degrees); subscripts L-B, FV, and RO denote LARISSA Site Beta, Faraday/Vernadsky, and Rothera, respectively. WS denotes the specific weather station relative to which $T_{\mathrm{L}-\mathrm{B}}$ is calculated (see Table 3 ).

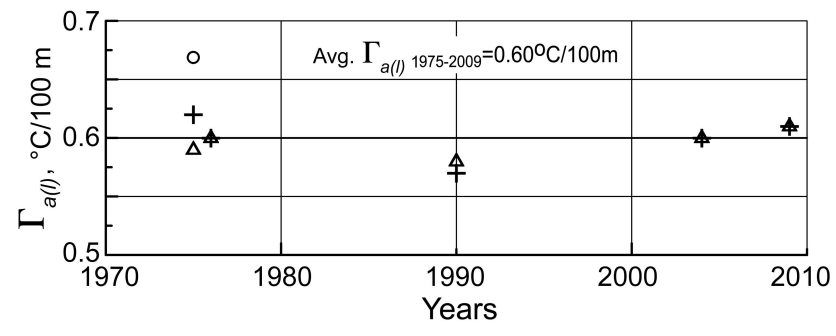

Fig. 3. LARISSA Site Beta altitudinal lapse rate calculated with respect to the Faraday/Vernadsky (crosses) and Rothera (triangles) weather stations; circle is Detroit Plateau mean value.

The results are shown in Table 3 and Fig. 3. Note that $\Gamma_{\mathrm{a}(1)}$ is calculated using a weather station-derived mean annual temperature record with a one year lag. Paterson (1994) estimated that the propagation of the winter minimum wave to $10 \mathrm{~m}$ depth required 5.5 months, and in general the previously defined $T_{\mathrm{S}}$ temperature represents the mean of the previous year's temperatures (with a small influence from preceding years as well). One can draw a similar conclusion from data presented by Morris and Vaughan (1994).

A relatively consistent value of $\Gamma_{\mathrm{a}(1)}=0.60^{\circ} \mathrm{C} / 100 \mathrm{~m}$ (Table 3) was obtained for the L-B site relative to the two stations. A uniform lapse rate relationship between sites implies that their climate histories are controlled by similar circulation, moisture flux, or heat flux changes.

Similar estimates of $\Gamma_{\mathrm{a}(1)}$ with respect to the Detroit Plateau (DP) $\left(64^{\circ} 05^{\prime} \mathrm{S}, 59^{\circ} 35^{\prime}, 1806 \mathrm{~m}\right.$ a.s.l.; $T_{10}=$ $-14.8^{\circ} \mathrm{C}$ in November of 1975; Martin and Peel, 1978; Morris and Vaughan, 2004) were conducted relative to the L-B site, FV, and RO. Estimated $\Gamma_{\mathrm{a}(1)}$ values for 1975 are $0.67^{\circ} \mathrm{C} / 100 \mathrm{~m}, 0.55^{\circ} \mathrm{C} / 100 \mathrm{~m}$, and $0.79^{\circ} \mathrm{C} / 100 \mathrm{~m}$, respectively (Table 3), with a mean $\Gamma_{\mathrm{a}(1)}=0.67^{\circ} \mathrm{C} / 100 \mathrm{~m}$ (Fig. 3). The $\Gamma_{\mathrm{a}(1)}$ values calculated with respect to DP are less consistent than those calculated with respect to the L-B site. This is likely due to the much larger year-to-year local variability in the single year comparisons relative to the smoothed records represented by the 11-yr means applied to FV and RO data, and the inherent smoothing of borehole temperature inversion results.

The mean value for the L-B site from our analysis with $\mathrm{FV}$ and $\mathrm{RO}$ is $\Gamma_{\mathrm{a}(1)}=0.60^{\circ} \mathrm{C} / 100 \mathrm{~m}$. For comparison, Martin and Peel (1978) estimated $\Gamma_{\mathrm{a}(1)}$ for the central and western regions of the Antarctic Peninsula at $0.68{ }^{\circ} \mathrm{C} / 100 \mathrm{~m}$, while Morris and Vaughan (2004) obtained $\Gamma_{\mathrm{a}(1)}=0.72{ }^{\circ} \mathrm{C} / 100 \mathrm{~m}$. A possible explanation would be the longer and more precise borehole temperature data and significantly longer weather station observation records used in our study. These values reveal temporal consistency of the local $\Gamma_{\mathrm{a}(1)}$ over the last $\sim 40 \mathrm{yr}$ despite mean temperature changes exceeding $2{ }^{\circ} \mathrm{C}$ that include periods of warming and cooling. 
Table 3. Altitudinal temperature lapse rate on the western side of the Antarctic Peninsula*.

\begin{tabular}{|c|c|c|c|c|c|}
\hline Period of time & $(\mathrm{L}-\mathrm{B})-\mathrm{FV}$ & $(\mathrm{L}-\mathrm{B})-\mathrm{RO}$ & $\mathrm{DP}-\mathrm{FV}$ & $\mathrm{DP}-\mathrm{RO}$ & $\mathrm{DP}-(\mathrm{L}-\mathrm{B})$ \\
\hline 2009 & 0.61 & & & & \\
\hline 2009 & & 0.61 & & & \\
\hline 1999-2009 & 0.6 & & & & \\
\hline 1999-2009 & & 0.6 & & & \\
\hline 1985-1995 & 0.57 & & & & \\
\hline 1985-1995 & & 0.58 & & & \\
\hline 1971-1981 & 0.6 & & & & \\
\hline $1971-1981$ & & 0.6 & & & \\
\hline 1975 & 0.6 & & 0.67 & 0.55 & 0.79 \\
\hline 1975 & & 0.6 & & & \\
\hline Mean & 0.60 & 0.60 & & & \\
\hline Standard dev. & 0.015 & 0.011 & & & \\
\hline
\end{tabular}

* Interpolated to $66^{\circ} \mathrm{S}$ latitude; see details in text; 1991-2009, 1985-1995 and 1971-1981 periods of time correspond to the values in Fig. 3 and shaded areas in Fig. 4.

\subsection{Regional comparison of $T_{\mathrm{S}}$ history for the AP}

Reconstructed $T_{\mathrm{s}}$ profiles from several key records of temperature (occupied weather stations, ice core isotope chemistry, and our L-B borehole temperature inversion) are shown in Fig. 4. The figure combines the ice core $\delta^{18} \mathrm{O}$ temperature proxy record from the Gomez ice core (Thomas et al., 2009), the $\delta \mathrm{D}$ ice core record from Dallinger Ice Cap ice core (Aristarain et al., 1990), weather station records for the Orcadas (OR), Faraday/Vernadsky (FV), and Rothera (RO), and inverted borehole temperature records from the Rutford Ice Stream ice core (Barrett et al., 2009) and Dolleman Island (Nicholls and Paren, 1993). The proxy temperature data and the weather station air temperature records are smoothed using an 11-yr window.

Figure 4 demonstrates three features of the climate history: (1) cooling conditions during the 19th century, (2) a relatively cold first half of the 20th century, and (3) a warming of $\sim 0.33{ }^{\circ} \mathrm{Cdecade}^{-1}$ since approximately 1950 . All the climatic features cited are observed in most northern Antarctic Peninsula ice core proxy temperature record from the Dallinger Ice Cap and in most southern site, the Rutford Ice Stream inverse $T_{\mathrm{S}}$. The Dolleman Island inverse $T_{\mathrm{S}}$ also demonstrates 19 th century cooling along the eastern coast of the Antarctic Peninsula. The stable isotopes proxy temperature profile from the Gomez site ice core represents high frequency $T_{\mathrm{S}}$ changes over the last $150 \mathrm{yr}$, relatively cold conditions from 1850 to 1950 , and rapid warming over the last $60 \mathrm{yr}$. Ice core proxy temperature profiles from Dyer Plateau (not shown; see Fig. 2; Mosley-Thompson et al., 2003) display a warming from 1940 to 1990 preceded by a relatively stable 300 -yr long period. The Siple Station ice core proxy temperature record (not shown; see Fig. 2; Mosley-Thompson et al., 2003) is characterized by rather stable temperatures over the last $500 \mathrm{yr}$. Neither of these ice core records contain the most recent two decades.
Most temperature profiles presented in Fig. 4 have a peak during the 1995-2000 period followed by recent cooling. Our reconstructed maximum $T_{\mathrm{S}}$ of $-14.2{ }^{\circ} \mathrm{C}$ corresponds to approximately 1995 , but our ability to determine the timing of the warmest temperatures is limited to $\pm 5 \mathrm{yr}$ due to thermal diffusion and assumption of constant precipitation rate. This peak is noteworthy, because $T_{\mathrm{S}}=>-15^{\circ} \mathrm{C}$ has been suggested as a threshold for the possibility of summer surface melting (Zagorodnov et al., 2006). With sufficient melt, percolation could raise the $T_{10}$ or $T_{15}$ temperature by up to $12{ }^{\circ} \mathrm{C}$ compared to conditions without melting (see Fig. 1 in Zagorodnov et al., 2006). There is abundant evidence of surface melting on the AP (e.g. Tedesco, 2009; Fahnestock et al., 2002). However, according to Vaughan (2006), there is a very narrow area at the crest of the Bruce Plateau where melting events are absent or very rare, and the L-B site is situated in this region. Radar backscatter for the L-B site is very low ( -20.9 to $-21.1 \sigma_{0}$, Radarsat Antarctic Mapping Project, Antarctic Mapping Mission - 1 data set; Jezek, 2002), consistent with a lack of refrozen melt layers within the firn.

Air temperature from a weather sensor on the PRT monitoring system recorded a few hours of above-freezing air temperatures on 6 March 2010 (maximum $1.1^{\circ} \mathrm{C}$ ), but it is unclear if the surface was above freezing at this time (sensor height was $5.8 \mathrm{~m}$ ). Although one might assume that the observed $T_{\mathrm{S}}$ peak at L-B might be associated with increased heat absorption during occasional melt periods in the mid1990 s, there is no evidence of melt-related structures at the corresponding depths in the L-B ice cores (40.8 to $72.0 \mathrm{~m}$ depth). The visible stratigraphy of the two LARISSA Site Beta ice cores reveals only a few very thin ice crusts in the entire firn section, only two thin $(<3 \mathrm{~mm})$ melt layers, and no evidence of percolation. Thus, we infer that surface snow melting at the L-B site is confined to rare events of short duration and does not affect the $T_{\mathrm{s}}$ value. 


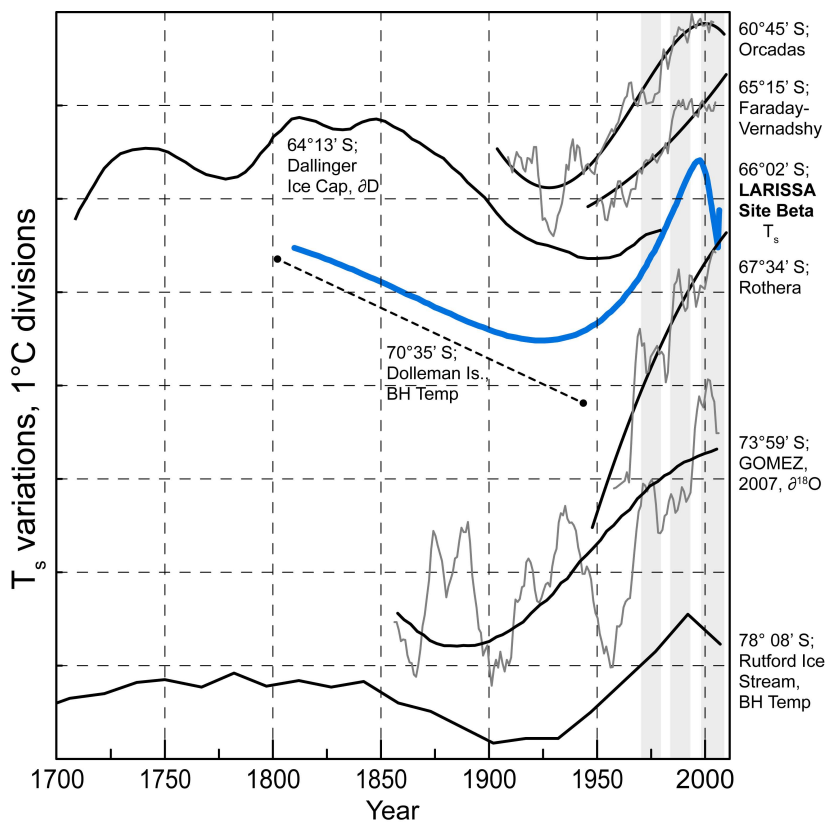

Fig. 4. Temperature histories from weather stations, borehole temperatures, and ice core isotope-derived records for sites on the Antarctic Peninsula and the adjacent West Antarctic Ice Sheet (see locations in Fig. 1). Shaded areas are the time intervals for which weather station data are available for the L-B $T_{\mathrm{S}}$ reconstructed data used in $\Gamma_{\mathrm{a}(1)}$ calculations (Table 3).

\section{Conclusions}

Borehole measurements along with steady state and inversion models allow an estimation of the following modern climatic parameters at LARISSA Site Beta:

- $T_{15}=T_{\mathrm{s}}=-14.8^{\circ} \mathrm{C}$, representing an approximate annual mean for the period February 2007 to January 2008;

- $T_{\mathrm{S} \text { max }}=-14.2^{\circ} \mathrm{C}$ in $1995( \pm 5 \mathrm{yr})$ is the warmest period during the last $70 \mathrm{yr}$ and is not associated with significant surface melting;

- $T_{\mathrm{S}}$ patterns are best described by a period of moderate temperatures in the 19th century, followed by cooling to a minimum early in the 20th century $\left(T_{\mathrm{s}}=\sim-16.1\right.$ near 1930 ), and then a warming to the maximum temperature in $\sim 1995$;

- The rate of warming over the last $\sim 70 \mathrm{yr}$ is $0.033^{\circ} \mathrm{C}$ $\mathrm{a}^{-1}$

- The lapse rate $\Gamma_{\mathrm{a}(1)}=0.60^{\circ} \mathrm{C} / 100 \mathrm{~m}$ for the region of the B-L borehole, Detroit Plateau, and Faraday-Vernadsky to Rothera; this relationship appears steady over the past few decades;

- $\dot{a}=1.90 \times 10^{3} \mathrm{~kg} \mathrm{~m}^{-2}$; possibly $\dot{a}\left(T_{\mathrm{s}}\right)=1.2 \times 10^{3}$ (at $-16.0^{\circ} \mathrm{C}$ ), $0.9 \times 10^{3}$ (at $\left.-17.0^{\circ} \mathrm{C}\right) \mathrm{kg} \mathrm{m}^{-2}$;
- $T_{\mathrm{b}}=-10^{\circ} \mathrm{C}$, and $q=88 \mathrm{~mW} \mathrm{~m}^{-2}$ and appears to have been steady over the last $200 \mathrm{yr}$.

The low-resolution climate history of the L-B site over the last $200 \mathrm{yr}$ demonstrates cooling from the mid-19th century to the early 20th century and is evident in the northern part of the Antarctic Peninsula on James Ross Island (Dallinger Ice Cap) as well as on Rutford Ice Stream far to the south. On the other hand, $\delta^{18} \mathrm{O}$-based temperature records from Siple Station, Dyer Plateau and Dolleman Island show much more modest temperature variations. These older records terminate prior to 1990. The more recent Gomez ice core (2007) reveals a warming rate comparable with that at the L-B site over recent decades.

Over the last $200 \mathrm{yr}$, the bottom temperature at L-B was roughly $10^{\circ} \mathrm{C}$ below the pressure melting point. However, on the Bruce Plateau the ice thickness in many locations exceeds $600 \mathrm{~m}$. Thus, the estimated basal heat flux of $88 \mathrm{~mW} \mathrm{~m}^{-2}$ at L-B is sufficient to support bottom melting in the vicinity of the drilling site. The heat dissipated in the bottom portion of a glacier in that region due to ice flow can contribute heat so that bottom melting can exist in areas with thinner ice, lower surface elevation and/or higher surface temperatures. Finally, the uniform lapse rate relationship calculated between the LB site and 2 permanent weather stations implies that their climate histories are controlled by similar circulation, moisture flux, or heat flux changes.

\section{Supplementary material related to this article is available online at: http://www.the-cryosphere.net/6/675/ 2012/tc-6-675-2012-supplement.pdf.}

Acknowledgements. This work was funded under NSF-OPP grants ANT-0732921 and ANT-0732655. We would like to thank A. Aristarain, Ana Teresa Gómez and E. Tomas for providing original data sets of temperatures and proxy temperatures for other sites in the Antarctic Peninsula. E. Morris and B. E. Barrett provided helpful advice, and J. Nicolas and D. Bromwich provided computational support and valuable insights. H. Brecher edited the first draft of the paper. We are indebted to the Rothera Station staff for their hospitality, and avionic, technical and moral support during field operations. VZ and EMT thank their field team members V. Mikhalenko, B. Vicencio, R. Filippi, and T. Verzone, whose efforts were essential for successful completion of the drilling project. Finally, we appreciate the generous support by our LARISSA colleagues and the Raytheon and Nathaniel B. Palmer support staff. This is Byrd Polar Research Center contribution number 1413.

Edited by: E. Larour 


\section{References}

Aristarain, A. J., Jouzel, J., and Lorius, C.: A 400 years isotope record of the Antarctic Peninsula climate, Geophys. Res. Lett., 17, 2369-2372, 1990.

Barrett, B. E., Nicholls, K. W., Murray, T., Smith, A. M., and Vaughan, D. G.: Rapid recent warming on Rutford Ice Stream, West Antarctica, from borehole thermometry, Geophys. Res. Lett., 36, L02708, doi:10.1029/2008GL036369, 2009.

Cook, A. J., Fox, A. J., Vaughan, D. G., and Ferrigno, J. G.: Retreating glacier fronts on the Antarctic Peninsula over the past half-century, Science, 308, 541-544, 2005.

Dahl-Jensen D., Mosegaard, K., Gundestrup, N., Clow, G. D., Johnsen, S. J., Hansen, A. W., and Balling, N.: Past temperatures directly from the Greenland Ice Sheet, Science, 282, 268-271, 1998.

Dahl-Jensen, D., Morgan, V. I., and Elcheikh, A.: Monte Carlo inverse modelling of the Law Dome (Antarctica) temperature profile, Ann. Glaciol., 29, 145-150, 1999.

Doake, C. S. M. and Vaughan, D. G.: Rapid disintegration of the Wordie Ice Shelf in response to atmospheric warming, Nature, 350, 328-330, 1991.

Duxbury, N. S., Zotikov, I. A., Nealson, K. H., Romanovsky, V. E., and Carsey, F. D.: A numerical model for an alternative origin of Lake Vostok and its exobiological implications for Mars, J. Geophys. Res., 106, 1453-1462, 2001.

Engelhardt, H.: Ice temperature and high geothermal flux at Siple Dome, West Antarctica, from borehole measurements, J. Glaciol., 50, 251-256, 2004.

Fahnestock, M. A., Shuman, C. A., and Abdalati, W.: Long melt seasons on ice shelves of the Antarctic Peninsula: an analysis using satellite-based microwave emission measurements, Ann. Glaciol., 34, 127-133, 2002.

Fricker, H. A., Scambos, T., Bindschadler, R., and Padman, L.: An active subglacial water system in West Antarctica mapped from space, Science, 315, 1544-1548, 2007.

Harris, R. N. and Chapman, D. S.: Borehole temperatures and a baseline for 20th-century global warming estimates, Science, 275, 1618-1621, 1997.

Jacobs, S. S. and Comiso, J. C.: Climate variability in the Amundsen and Bellingshausen Seas, J. Clim., 10, 697-709, 1997.

Jezek, K.: RAMP AMM-1 SAR image mosaic of Antarctica, Digital Media, Alaska Satellite Facility in association with National Snow and Ice Data Center, 2002.

Lee, T. and McPhaden, M. J.: Increasing intensity of El Niño in the central-equatorial Pacific, Geophys. Res. Lett., 37, L14603, doi:10.1029/2010GL044007, 2010.

MacAyeal, D. R., Firestone, J., and Waddington, E.: Paleothermometry by control methods, J. Glaciol., 37, 326-338, 1991.

Martin, P. J. and Peel, D. A.: The spatial distribution of $10 \mathrm{~m}$ temperatures in the Antarctic Peninsula, J. Glaciol., 20, 311-317, 1978.

Maule, C. F., Purucker, M. E., Olsen, N., and Mosegaard, K.: Heat flux anomalies in Antarctica revealed by satellite magnetic data, Science, 309, 464-467, 2005.

Monaghan, A. J., Bromwich, D. H., and Schneider, D. P.: Twentieth century Antarctic air temperature and snowfall simulations by IPCC climate models, Geophys. Res. Lett., 35, L07502, doi:10.1029/2007GL032630, 2008.
Morris, E. M. and Vaughan, D. G.: Snow surface temperatures in West Antarctica, Antarctic Science, 6, 529-535, 1994.

Morris, E. M. and Vaughan, D. G.: Spatial and temporal variation of surface temperature on the Antarctic Peninsula and the limit of variability of ice shelves, in Antarctic Peninsula climate variability: Antarctic Peninsula Climate Variability: Historical and Paleoenvironmental Perspectives, Ant. Res. Ser., 79, 61-68, doi:10.1029/AR079, 2003.

Mosley-Thompson, E. and Thompson, L. G.: Ice core paleoclimate histories from the Antarctic Peninsula: Where do we go from here?, in: Antarctic Peninsula Climate Variability: Historical and Paleoenvironmental Perspectives, Ant. Res. Ser., 79, 115-127, doi:10.1029/AR079, 2003.

Mosley-Thompson, E., Dai, J., Thompson, L. G., Grootes, P. M., Arbogast, J. K., and Paskievitch, J. F.: Glaciological studies at Siple Station (Antarctica): potential ice-core paleoclimatic record, J. Glaciol., 37, 11-22, 1991.

Muto, A., Scambos, T., Steffen, K., and Clow, G.: Recent surface temperature trends in the interior of East Antarctica from borehole firn temperature measurements and geophysical inverse methods, Geophys. Res. Lett., 38, L15502, doi:10.1029/2011GL048086, 2011.

Nagornov, O. V., Konovalov, V., Zagorodnov, V. S., and Thompson, L. G.: Reconstruction of the surface temperature of Arctic glaciers from the data of temperature measurements in wells, J. Eng. Thermophys., 74, 253-265, 2001.

Nagornov, O. V., Konovalov, Y. V., and Tchijov, V.: Temperature reconstruction for Arctic glaciers, Palaeogr. Palaeocl. Palaeoec., 236, 125-134, 2006.

Nicholls, K. W. and Paren, J. G.: Extending the Antarctic meteorological record using ice-sheet temperature profiles, J. Climate, 6 , 141-150, 1993.

Paterson, W. S. B.: The Physics of Glaciers, Elsevier, Oxford, 1994.

Peel, D. A. and Clausen, H. B.: Oxygen-isotope and total betaradioactivity measurements on $10 \mathrm{~m}$ ice cores from the Antarctic Peninsula, J. Glaciol., 28, 43-55, 1982.

Peel, D. A., Mulvaney, R., and Davison, B. M.: Stable-isotope/airtemperature relationships in ice cores from Dolleman Island and the Palmer Land Plateau, Antarctic Peninsula, Ann. Glaciol., 10, 130-136, 1988.

Pettit, E. and Waddington, E.: Ice flow at low deviatoric stress, J. Glaciol., 49, 359-369, 2003.

Pettit, E., Scambos, T., Truffer, M., Bauer, R., Mosley-Thompson, E., Zagorodnov, V., Haran, T., Ross, R., Blair, B., and Joughin, I.: The Bruce Plateau Ice Cap: Upstream Dynamics of the Southern Larsen B Ice Shelf, Geophysical Research Abstracts v13, EGU General Assembly 2011, EGU 2011-2698, 2011.

Pollack, H. N. and Huang, S.: Climate reconstruction from subsurface temperatures, Ann. Rev. Earth Planet. Sci., 28, 339-365, 2000.

Pollack, H. N., Hurter, S. J., and Johnson. J. R.: Heat flow from the Earth's interior: Analysis of the global data set, Rev. Geophys, 31, 267-280, 1993.

Price, P. B., Nagornov, O., Bay, R., Chirkin, D., He, Y., Miocinovic, P., Richards, A., Woschnagg, K., Koci, B., and Zagorodnov, V.: Temperature profile for glacial ice at the South Pole: implications for life in a nearby subglacial lake, P. Natl. Acad. Sci., 99, 78447847, 2002. 
Radok, U., Jenssen, D., and Budd, W.: Steady-state temperature profiles in ice sheets, Intl. Assoc. Scientific Hydrology Publication No. 86, 151, 1970.

Rignot, E., Casassa. G., Gogineni, P., Krabill, W., Rivera, A., and Thomas, R.: Accelerated ice discharge from the Antarctic Peninsula following the collapse of Larsen B ice shelf, Geophys. Res. Lett., 31, L18401, doi:10.1029/2004GL020697, 2004.

Ritz, C.: Time dependent boundary conditions for calculation of temperature fields in ice sheets, IAHS, 170, 207-216, 1987.

Salamatin A. N.: Paleoclimatic reconstructions based on borehole temperature measurements in ice sheets. Possibilities and limitations, in: Physics of Ice Core Records, edited by: Hondoh, T., Hokkaido University Press, Sapporo, 243-282, 2000.

Scambos, T. A., Hulbe, C., and Fahnestock, M. A.: Climate-induced ice shelf disintegration in the Antarctic Peninsula, in: Antarctic Peninsula Climate Variability: Historical and Paleoenvironmental Perspectives, Ant. Res. Ser., 79, 79-92, doi:10.1029/AR079, 2003

Scambos, T. A., Shuman, C. A., and Berthier, E.: The triggering of subglacial lake drainage during rapid glacier drawdown: Crane Glacier, Antarctic Peninsula, Ann. Glaciol., 52, 74-82, 2011.

Schneider, D. P. and Steig, E. J.: Ice cores record significant 1940s Antarctic warmth related to tropical climate variability, P. Natl. Acad. Sci., 105, 12154-12158, 2008.

Shapiro, N. M. and Ritzwoller, M. H.: Inferring surface heat flux distributions guided by a global seismic model: particular application to Antarctica, Earth Planet. Sci. Lett., 223, 213-224, 2004.

Siegert, M. J. and Dowdeswell, J. A.: Spatial variations in heat at the base of the Antarctic ice sheet from analysis of the thermal regime above sub-glacial lakes, J. Glaciol., 42, 501-509, 1996.

Stammerjohn, S. E., Martinson, D. G., Smith, R. C., Yuan, X., and Rind, D.: Trends in Antarctic annual sea ice retreat and advance and their relation to El Niño-Southern Oscillation and Southern Annular Mode variability, J. Geophys. Res., 108, C03S90, doi:10.1029/2007JC004269, 2008.

Tedesco, M.: Assessment and development of snowmelt retrieval algorithms over Antarctica from K-band spaceborne brightness temperature (1979-2008), Remote Sens. Environ., 113, 979997, 2009

Thomas, E. R., Marshall, G. J., and McConnell, J. R.: A doubling in snow accumulation in the western Antarctic Peninsula since 1850, Geophys. Res. Lett., 35, L01706, doi:10.1029/2007GL032529, 2008.

Thomas, E. R., Dennis, P. F., Bracegirdle, T. J., and Franzke, C.: Ice core evidence for significant 100-year regional warming on the Antarctic Peninsula, Geophys. Res. Lett., 36, L20704, doi:10.1029/2009GL040104, 2009.

Thompson, L. G., Peel, D. A., Mosley-Thompson, E., Mulvaney, R., Dai, J., Lin, P. N., Davis, M. E., and Raymond, C. F.: Climate since A.D. 1510 on Dyer Plateau, Antarctic Peninsula: Evidence for recent climate change, Ann. Glaciol., 20, 420-426, 1994.

Tikhonov, A. N. and Samarskii, A. A.: Equations of Mathematical Physics, Dover Publications, 1990.

Turner, J., Colwell, S. R., and Harangozo, S.: Variability of precipitation over the coastal western Antarctic Peninsula from synoptic observations, J. Geophys. Res., 102, 13999-14007, 1997.
Turner, J., Lachlan-Cope, T. A., Marshall, G. J., Morris, E. M., Mulvaney, R., and Winter, W.: Spatial variability of Antarctic Peninsula net surface mass balance, J. Geophys. Res., 107, L14603, doi:10.1029/2001JD000755, 2002.

Turner, J., Lachlan-Cope, T., Colwell, S., and Marshall, G. J.: A positive trend in western Antarctic Peninsula precipitation over the last 50 years reflecting regional and Antarctic-wide atmospheric circulation changes, Ann. Glaciol., 41, 85-91, 2005.

van de Wal, R. S. W., Mulvaney, R., Isaksson, E., Moore, J. C., Pinglot, J.-F., Pohjola, V., and Thomassen, M. P. A.: Reconstruction of the historical temperature trend from measurements in a medium-length bore hole on the Lonomosovfonna Plateau, Svalbard, Ann. Glaciol., 35, 371-378, 2002.

van den Broeke, M.: Strong surface melting preceded collapse of Antarctic Peninsula ice shelf, Geophys. Res. Lett., 32, L12815, doi:10.1029/2005GL023247, 2005.

van Lipzig, N. P. M., King, J. C. Lachlan-Cope, T. A., and van den Broeke, M. R.: Precipitation, sublimation, and snow drift in the Antarctic Peninsula region from a regional atmospheric model, J. Geophys. Res., 109, D24106, doi:10.1029/2004JD004701, 2004.

Vaughan, D. G.: Recent trends in melting conditions on the Antarctic Peninsula and their implications for ice-sheet mass balance and sea level, Arct. Antarct. Alp. Res., 38, 147-152, 2006.

Vaughan, D. G. and Doake, C. S. M.: Recent atmospheric warming and retreat of ice shelves on the Antarctic Peninsula, Nature, 379, 328-331, 1996.

Vaughan, D. G., Marshall, G. J., Connolley, W. M., Parkinson, C., Mulvaney, R., Hodgson, D. A., King, J. C., Pudsey, C. J., and Turner, J.: Recent rapid regional climate warming on the Antarctic Peninsula, Climatic Change, 60, 243-274, doi:10.1023/A:1026021217991, 2003.

Waddington, E. D.: Geothermal heat flux beneath ice sheets, IAHS, 170, 217-226, 1987.

Zagorodnov, V. S., Morev, V. A., Nagornov, O. V., Kelley, J. J., Gosink, T. A., and Koci, B. R.: Hydrophilic liquid in glacier boreholes, Cold Reg. Sci. Technol., 22, 243-251, 1994.

Zagorodnov, V., Thompson, L. G., Kelley, J. J., Koci, B., and Mikhalenko, V.: Antifreeze thermal ice core drilling: an effective approach to the acquisition of ice cores, Cold Reg. Sci. Technol., 28, 189-202, 1998.

Zagorodnov, Z., Thompson, L. G., Ginot, P., and Mikhalenko, V.: Intermediate depth ice coring of high altitude and polar glaciers with a light-weight drilling system, J. Glaciol., 51, 491-501, 2005.

Zagorodnov, V., Nagornov, O., and Thompson, L. G.: Influence of air temperature on a glacier's active-layer temperature, Ann. Glaciol., 43, 285-291, 2006.

Zotikov, I. A.: Bottom melting in the central zone of the Antarctic Ice Sheet and its influence on the present balance of the ice mass, Bull. Int. Assoc. Sci. Hydrol., 8, 36-44, 1963.

Zotikov, I. A.: The Thermophysics of Glaciers, D. Reidel, Dordrecht, 1986. 